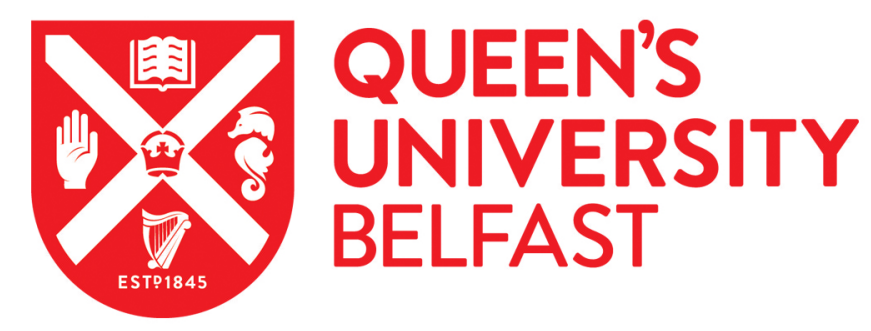

\title{
UK charities and the pandemic: Navigating the perfect storm
}

Hyndman, N. (2020). UK charities and the pandemic: Navigating the perfect storm. Journal of Accounting \& Organizational Change, 16(4), 587-592. https://doi.org/10.1108/JAOC-08-2020-0114

Published in:

Journal of Accounting \& Organizational Change

Document Version:

Peer reviewed version

Queen's University Belfast - Research Portal:

Link to publication record in Queen's University Belfast Research Portal

Publisher rights

Copyright 2020 Emerald. This work is made available online in accordance with the publisher's policies. Please refer to any applicable terms of use of the publisher.

\section{General rights}

Copyright for the publications made accessible via the Queen's University Belfast Research Portal is retained by the author(s) and / or other copyright owners and it is a condition of accessing these publications that users recognise and abide by the legal requirements associated with these rights.

Take down policy

The Research Portal is Queen's institutional repository that provides access to Queen's research output. Every effort has been made to ensure that content in the Research Portal does not infringe any person's rights, or applicable UK laws. If you discover content in the Research Portal that you believe breaches copyright or violates any law, please contact openaccess@qub.ac.uk. 


\title{
Accepted Paper Journal of Accounting \& Organizational Change (Accepted 17 ${ }^{\text {th }}$ September 2020)
}

\section{UK charities and the pandemic: Navigating the perfect storm}

\author{
Noel Hyndman \\ Centre for Not-for-profit and Public-sector Research at Queen's University Belfast
}

\begin{abstract}
Purpose - Discuss the impact of COVID-19 on the UK charity sector, outline possible opportunities for researchers in accounting/management as a consequence, and discuss possible strategies to respond to the pandemic.

Design/methodology/approach - Literature-based personal critical reflection.

Findings - COVID-19 has created a perfect storm for charities as major swathes of income have been lost, demands on services have increased and some are unable to operate at all because of imposed constraints.

Originality/value - Possible avenues for research, arising from the context of the crisis in the sector, are highlighted. Moreover, several useful strategies are emphasised to enable charities to navigate the crisis.
\end{abstract}

Keywords COVID-19, charities, crisis management

Paper type Viewpoints

\section{The UK charity sector and COVID-19}

Charitable organisations are pervasive. They focus on goals of a philanthropic nature that are deemed by individual societies to serve the public interest. As a consequence, what is 'charitable' may vary according to jurisdiction. In the UK there are over 200,000 registered charities with an estimated total annual income approaching $£ 80$ billion, and the sector includes such well-known names as Cancer Research, Save the Children Fund and the Royal National Lifeboat Institution. It is commonly expected that charities will both 'do good' and 'be good' (Hyndman, 2018). They are very different from either the private or the public sectors in terms of orientation, motivation, activities, sources of funding and contribution to the public good. They are mission driven and exist to provide public benefit; they are non-profit, and are often largely funded and supported by individuals or organisations that receive no direct economic benefit; and they contribute to the public good, often providing a foundation for social cohesiveness. As such, they are organisations to be valued, nurtured, protected and encouraged by the whole of society.

The COVID-19 pandemic spread to the UK in early 2020. Some key milestones relating to the outbreak and spread of the virus in the UK were: the first two positive tests on the $29^{\text {th }}$ January 2020; the first British death, $28^{\text {th }}$ February; surge in reported cases, $4^{\text {th }}$ March (34 cases, bringing the total to 87 ); government ordered major social venues to close (20 ${ }^{\text {th }}$ March); highest 
daily deaths (938) on $9^{\text {th }}$ April. At the time of writing ( $5^{\text {th }}$ September 2020), there had been 342,351 confirmed cases and 41,537 deaths in the UK, placing it amongst the most affected major countries in terms of death rate per capita (UK Government, 2020). The objectives of this personal reflective research note are to: discuss the impact of COVID-19 on the UK charity sector and then highlight areas for future academic research. In doing this, related practical/applied implications are also discussed and useful strategies highlighted to enable charities to navigate the crisis. While the focus of the comment and analysis, and the examples used, will largely consider the UK charity sector, the matters that it raises are likely to be similar in most non-profit organisations, regardless of jurisdiction.

\section{The perfect storm}

The effect of COVID-19 on the charity sector has been huge. While the consequences for individual charities depend on a number of variables, the overall impact on the sector as a whole is that of a 'perfect storm'. Access to key funding streams has suffered, as individuals are furloughed or laid off, fundraising events have been cancelled, and, because of lockdown requirements, volunteers are reluctant (or unable) to engage in providing support. At the same time, need in many charities, particularly those relating to social welfare and mental health, has increased substantially. In June 2020, Pro Bono Economics (PBE) (2020) estimated that, over the subsequent six months alone, UK charities were facing a $£ 10.1$ billion funding gap as a result of COVID-19, with incomes expected to drop by $£ 6.7$ billion, at the same time as demand for their support would rise by the equivalent of $£ 3.4$ billion.

In addition, other reports warn of the imminent collapse of well-known and wellestablished charities as demands increase and reserves are burnt through in trying to maintain essential services as income sources dry up. Moreover, additional government support has often been viewed as inadequate and coming too slow to avoid severe consequences for society at large. Almost immediately following the lockdown in the UK (March 2020), many charities took speedy action to reduce their outgoings in response to the financial challenges: for example, 61 per cent furloughed staff under the UK Government's Job Retention Scheme and 59 per cent significantly reduced their activity (PBE, 2020). On the fundraising side, many high-profile events have been hit. For example, the 2020 London marathon, which raised over $£ 60$ million for good causes in 2019, was postponed until October 2020. Even then, it was restricted to elite athletes, thereby certainly resulting in significant reductions in fundraising. In addition, an array of regular local fundraising events (fetes, coffee mornings, sponsored walks) were cancelled (Institute of Fundraising, 2020). Given this scenario, charities have grappled with decisions regarding what to do. For example: what should be prioritised, what influence do particular types of spending have, and, if cutbacks in spending are to occur, where will their effect be least felt?

\section{Opportunities for researchers and actions by charities}

COVID-19 is an evolving humanitarian crisis that has affected all countries and has impacted massively on people's lives. Charities are often key to the well-being of a civilised, cohesive and caring society, particularly as facilitators for generating social capital. However, charities are particularly fragile organisational forms because of the (possibly extensive) demands relating to their (often ambitious) social missions and their enormous dependence on the willing engagement of a range of external stakeholders, many of whom act with altruistic motives (e.g. donors and volunteers). Moreover, issues of trust, ethics, legitimacy and competency often emerge as barriers to their growth and development.

The above factors have come into particular focus during the present pandemic and have impacted hugely on the ability of charities to function normally, or even function at all (hence the 'perfect storm'). So what can charities do, and what research should be pursued to 
help them in the challenges ahead? Even in stable situations, conducting and disseminating theoretically-informed, rigorous empirical analysis in the charity area is essential. Research can be used as a basis for judging proposed (and even previously implemented) changes, as well as supporting policy makers and decision makers as the grapple with an uncertain future. In addition, (hopefully) relevant research can be drawn upon to counter what, at times, seems like a pervasive momentum towards the implementation of managerial 'solutions' in a sector where, frequently, these are inappropriate (Hyndman, 2017). In a time of crisis, research becomes even more vital. While a range of COVID-19-related research issues relevant to the sector have value, for brevity I focus on three (interlinked) areas, considering, not only possible further research, but also practical/applied implications relating to each.

\subsection{Fundraising approaches}

In the COVID-19 emergency, funding flows have been massively damaged. Therefore, research into the effectiveness (as well as ethical appropriateness) of fundraising strategies is critical. This may be related to considerations of why donors give to charities; given the present pandemic, many charities have ramped-up fundraising efforts by identifying and targeting financially-stable existing/potential donors. The need for charities to establish legitimacy as a basis for building trust and securing funding, while essential, is fraught with challenges (Alexander et al., 2010). Scandals (and resulting damage to reputation) and the dangers of questionable and over-aggressive fundraising practices are very real. In the UK, the 'Olive Cooke affair' in 2015 triggered hundreds of complaints from the public, a high-level examination of fairly widespread dubious fundraising practices and the establishment of a new UK Fundraising Regulator (Hind, 2017).

From a practical perspective, reaching out to particularly committed donors is one way of shoring up resource inflows (HM Government 2020; Third Sector, 2020), albeit some donors have reduced ability to respond because of COVID-19 hits on their finances. Samkin and Schneider (2010) have argued that organisational survival and success requires stakeholder support (particularly from donors), and therefore management needs to legitimate the charity by demonstrating the organisation's values, beliefs and successes. At the present time, this would seem particularly apposite. Therefore, identifying possible targets from existing donor lists and communicating (either directly, if possible, or through emergency appeal messaging) with them regarding the 'charity COVID-19 story' would seem a prudent way forward.

In addition, charities themselves would be well advised to access whatever support is available. In the UK, government had developed a scheme (operated from March 2020) to deal with the immediate employee-related impact of COVID-19, whereby organisations, including charities, got support to pay wages through the Coronavirus Job Retention Scheme (allowing payment of up to $80 \%$ of an employee's salary). Wisely, many charities accessed such funding (the scheme closed in October 2020). In addition, government allocated an extra $£ 750$ million in direct funding to ensure charity and voluntary organisations could continue their vital work.

The need for charities, and particularly umbrella groups representing the sector, to work with, and lobby, government as the crisis unfolds would also seem critical. A recent example of this was evidenced in a report published by a major UK House of Commons committee (House of Commons, 2020), where 71 charities provided written evidence and three senior representatives of the sector gave evidence in person. As a consequence, the committee called on the UK Government to both increase the support available to charities through a comprehensive stabilisation fund and to adapt existing support schemes for businesses to ensure they provided appropriate support for the charity sector. Time will tell how this unfolds.

\subsection{Performance-management frameworks}


More research into how to develop and use performance-management frameworks, with a particular focus on indicators of impact/outcome, would assist the steering of charity management. This is especially critical (and sensitive) when decisions have to be made regarding reductions in activity. Relevant impact/outcome information can facilitate more effective, and beneficiary-centred, decisions, as well as supporting external reporting (an important input to building legitimacy). Recent work relating to the New Zealand charity sector (Yang and Northcott, 2018) exploring outcome measurement is a useful exemplar here. Good performance-management systems can underpin attempts to safeguard the health and growth of the sector, and public interest generally (Hyndman and McConville, 2018).

Obviously, given the current situation, many charities are very concerned about their financial position. From an operational perspective, it would seem judicious that they reflect on their short, medium and longer-term priorities, and consider the likely need to amend their financial planning. Charities are encouraged in particular to think about whether or not certain projects, spends or activities can be stopped or delayed in order to focus on essential spending (HM Government, 2020). Performance-management frameworks have potential to support such deliberations.

Linked to this, are issues relating to reserves and reserves policy. Reserves are that part of a charity's unrestricted funds that is freely available to spend. Reserves help protect a charity against drops in income, and drops in income as a consequence of COVID-19 have been severe. Many charities have been using whatever reserves they have to meet (often increasing) needs. 'Too high' a level of reserves might suggest that a charity is not focused on delivery of service, with 'too low' a figure possibly indicating vulnerability and poor planning. A rough, presentlyaccepted indicator in the sector is that a charity should aim at having reserves somewhere between three to nine months of expenditure.

The extant UK charity Statement of Recommended Practice (SORP) (Charity Commission, 2014) requires that a charity must report and explain its policy for holding reserves and highlight why they are held. This is to encourage charities to consider carefully an appropriate level to target. However, recent analysis of the largest UK charities suggests that a number have reserves levels as low as one month of expenditure (Third Sector, 2020), suggesting a major weakness. The present crisis should motivate charities to reengage with the question of reserves policy. Moreover, for the sector as a whole and given COVID-19, it might be prudent to adjust the present accepted benchmark for reserve levels upwards, and for charities to act to achieve it.

\subsection{Beneficiary engagement}

An important consideration in any charity is the degree to which beneficiaries are involved in the decision-making functions; this is especially important at a time when adjustments to services have to be made. Beneficiary interests represent the heart of the mission of a charity. Therefore, input from beneficiaries in decision making and governance (if at all possible) may be crucial in sharpening the mission focus, as well as being viewed as 'right and good' (Locke et al., 2003, p. 57). The ways in which this might be achieved, the benefits and consequences of it, and the connections between different stakeholder views and interests relating to it, seem particularly useful areas for further investigation.

For some charities, the crisis has not changed what they do for beneficiaries, but has impacted on how they do it. Some services have been moved online, although the inability to provide services face-to-face possibly disadvantages particularly vulnerable beneficiaries. For other charities, the measures to combat COVID-19 actually prevent the mission of the charity being delivered at all (for example, in charities involved in outward-bound activities for young people). Still other charities find that more is being asked of them, with the loss of jobs and income (and enforced isolation) impacting on mental health and poverty. Each of these 
challenges needs to be managed carefully to ensure that beneficiary interest is not undermined, while recognising that service delivery may have to be adjusted in the light of reduced financial circumstances. Evidence regarding the impact of particular charity interventions, in addition to well-thought-out consultations with beneficiaries, would help in underpinning managerial decisions in these areas.

\section{Some final comments}

COVID-19 is having an irrefutable impact on the UK's charity sector. It has created a perfect storm, as major swathes of income have been lost and demands on services have increased. In such a context, what should charities be doing and, as researchers, how might the pandemic influence our research agendas? The crisis presents particular opportunities for academics to pursue research. Three areas are highlighted here. Firstly, work to identify the effectiveness, and ethical suitability, of fundraising strategies; this might go some way to helping charities plug the income gap created by the pandemic. Secondly, research into performance frameworks; this has the capacity to support decision making within, and improve accountability by, charities. Finally, explore ways to achieve greater beneficiary engagement in the governance processes; this could sharpen mission-focussed decision making and help to build legitimacy (particularly with donors). In addition, the paper also highlights the critical need for charities to navigate the crisis wisely in order to safeguard beneficiary interest (immediately and going forward): by pursuing strategies to access (or lever) additional funding, by considering how limited reserves can be used effectively in delivering benefit and by working with key stakeholder groups.

UK charities contribute so much to creating and sustaining a caring society; they engage in varied, valuable and socially-desirable activities that reflect key cultural values central to the liberal democracy that is the UK. It is hoped by the writer, and by all those with a heart for the excellent work that charities do, that COVID-19 is only an unfortunate blip in the growth and development of a sector that contributes so much towards the building of valuable social capital. The combined upshot of embracing strategies to deal immediately with the pandemic, and encouraging research to underpin changes as charities emerge from the crisis, has the potential to facilitate charities in taking steps to ensure they are well-placed to survive the current crisis, and then prosper beyond it.

Noel Hyndman is Professor of Accounting and Director of the Centre for Not-for-profit and Public-sector Research at Queen's University Belfast. He has held Visiting Professorships at the University of Ottawa and the University of Sydney, as well as being an Erskine Fellow at the University of Canterbury in New Zealand. Noel has been was a member of the UK Charity Statement of Recommended Practice (SORP) Committee since 2006. He is Associate Editor of both Financial Accountability \& Management and Abacus. Currently he is Chair of the British Accounting and Finance Association's Public Services and Charities Special Interest Group.

\section{References}

Alexander, J., Brudney, J.L. and Yang, K. (2010), 'Introduction to the symposium: accountability for performance and measurement: the evolving role of nonprofits in the hollow state', Nonprofit and Voluntary Sector Quarterly, Vol. 39, No. 4, pp.565-570.

Charity Commission (2014), Charities SORP (FRS 102) Accounting and reporting by charities: statement of recommended practice, Charity Commission, London. 
HM Government (2020), Coronavirus (COVID-19) guidance for the charity sector, HM Government, London. Accessed 5 September 2020:

https://www.gov.uk/guidance/coronavirus-covid-19-guidance-for-the-charity-sector

House of Commons (2020), The Covid-19 crisis and charities, HC 281, House of Commons, London. Accessed 5 September 2020:

https://committees.parliament.uk/publications/938/documents/7200/default/

Hind, A. (2017), 'Fundraising in UK charities: stepping back from the abyss', Public Money \& Management, Vol. 37, No. 3, pp.205-210.

Hyndman, N. (2017), 'The charity sector: changing times, changing challenges', Public Money \& Management, Vol. 37, No. 3, pp.149-153.

Hyndman, N. (2018), 'The Charities SORP: an 'engine' for good?', Public Money \& Management, Vol. 38, No. 4, pp.247-250.

Hyndman, N. and McConville, D. (2018), 'Making charity effectiveness transparent: building a stakeholder-focused framework of reporting', Financial Accountability \& Management, Vol. 34, No. 2, pp.133-147.

Institute of Fundraising (2020), Round-Up: Coronavirus Impact on Charities, Institute of Fundraising, $19^{\text {th }}$ June. Accessed 5 September 2020:

https://www.institute-of-fundraising.org.uk/guidance/coronavirus/round-up-coronavirusimpact-on-charities/

Locke, M., Begum, N. and Robson, P. (2003), 'Service users and charity governance', Cornforth, C., (Ed.), The Governance of Public and Non-Profit Organizations: What do boards do? Routledge, Oxford.

Pro Bono Economics (2020), Charities facing 110.1 billion funding gap over the next six months, Pro Bono Economics, 9th June. Accessed 5 September 2020:

https://www.probonoeconomics.com/news/charities-facing-\%C2\%A3101-billion-fundinggap-over-next-six-months

Samkin, G. and Schneider, A. (2010), 'Accountability, narrative reporting and legitimation: the case of a New Zealand public benefit entity', Accounting, Auditing \& Accountability Journal, Vol. 23, No. 2, pp.256-289.

Third Sector (2020), 'Analysis: how charities with low reserves are coping with the Covid-19 pandemic', Third Sector, $8^{\text {th }}$ April. Accessed 5 September 2020:

https://www.thirdsector.co.uk/analysis-charities-low-reserves-coping-covid-19pandemic/finance/article/1679646

UK Government (2020), Coronavirus (COVID-19) in the UK. Accessed 5 September 2020: https://coronavirus.data.gov.uk/

Yang, C. and Northcott, D. (2018), 'Unveiling the role of identity accountability in shaping charity outcome measurement practices', British Accounting Review, Vol. 50, No. 2, pp.214-226. 